\begin{tabular}{|ll|}
\hline Received & $:$ 30 Maret 2019 \\
Revised & $: 4$ April 2019 \\
Accepted & $: 22$ April 2019 \\
Online & $: 28$ April 2019 \\
Published & $:$ 30 April 2019 \\
\hline
\end{tabular}

\title{
IDENTIFIKASI TANAMAN HANJUANG (CORDYLINE FRUTICOSA) DI KEBUN RAYA BOGOR SEBAGAI TANAMAN LANSKAP BERDASARKAN MORFOLOGI DAN ANATOMINYA
}

\author{
Imam Safir Alwan Nurza ${ }^{1)}$ \\ ${ }^{1}$ Biologi, Fakultas Matematika dan Ilmu Pengetahuan Alam, Universitas Negeri Jakarta \\ email: imamsafiralwannurza2017@gmail.com
}

\begin{abstract}
Hanjuang (Cordyline fruticosa) is perennial plant which has function as protective plant and barrier in rice fields or fields. The research purpose was to determine Hanjuang (Cordyline fruticosa) plant based on morphology and anatomy. The research method used was descriptive qualitative. Samples were taken at Bogor Botanical Gardens. The anatomy Observed under microscope light with magnification 100-400 times. The research resulted that leaves morphology showed pointed apical and base, arrangement pinnate bones, flesh like paper, lanceolate shape, smooth surface, choppy edges, bright purple when exposed to sunlight and purple when is not, and type leaf sheath. Moreover, leaves, stems, and roots have support tissue in form of colenchyma. The anatomy of stem and root showed transport tissue but xylem observed larger than its phloem. Root showed radially shape. Leaves has an actinositic stomata and content ergastic in the form of needle crystals. Leaves could be seen purple in water and changes when to yellow and green after some drops of basic solutions. It showed that Hanjuang (Cordyline fruticosa) leaves contain anthocyanin but no carotenoid.
\end{abstract}

Keywords: Anatomy, Hanjuang plant (Cordyline fruticosa), Leaves, Morphology, Root, Stem

\begin{abstract}
Abstrak
Hanjuang (Cordyline fruticosa) adalah tanaman tahunan yang berfungsi sebagai tanaman pelindung dan penghalang di sawah atau ladang. Tujuan penelitian adalah menentukan tanaman Hanjuang (Cordyline fruticosa) berdasarkan morfologi dan anatomi. Metode penelitian yang digunakan adalah deskriptif kualitatif. Sampel diambil di Kebun Raya Bogor. Anatomi yang diamati di bawah cahaya mikroskop dengan perbesaran 100-400 kali. Hasil penelitian menunjukkan bahwa morfologi daun menunjukkan apikal dan pangkal runcing, susunan tulang menyirip, daging seperti kertas, bentuk lanset, permukaan halus, tepi berombak, ungu cerah saat terpapar sinar matahari dan ungu saat tidak, dan ketik selubung daun. Selain itu, daun, batang, dan akar memiliki jaringan pendukung dalam bentuk colenchyma. Anatomi batang dan akar menunjukkan jaringan transportasi tetapi xilem diamati lebih besar dari floemnya. Akar menunjukkan bentuk radial. Daun memiliki stomata actinositic dan konten ergastik dalam bentuk kristal jarum. Daun bisa terlihat ungu dalam air dan berubah kapan menjadi kuning dan hijau setelah beberapa tetes larutan dasar. Ini menunjukkan bahwa daun Hanjuang (Cordyline fruticosa) mengandung antosianin tetapi tidak mengandung karotenoid.
\end{abstract}

Kata kunci: Anatomi, tanaman Hanjuang (Cordyline fruticosa), Daun, Morfologi, Akar, Batang.

\section{PENDAHULUAN}

Kebun Raya Bogor merupakan kebun botani yang mengoleksi berbagai macam tumbuhan dan tanaman serta menjadi tempat lembaga penelitian di Indonesia dalam bidang biologi dan pertanian, seperti Herbarium Bogoriense, Treub Laboratorium, Bibliotheca Bogoriense, Griya Anggrek, Taman Soedjana Kassan, dan lain-lain. Kebun Raya Bogor juga merupakan tempat konservasi secara ex-situ di Indonesia. Luas Pusat Konservasi Tumbuhan Kebun Raya Bogor mencakup area 87 Hektar. Subarna A., (2003) Jumlah koleksinya terakhir tercatat mencapai 13.714 spesimen. Koleksi tanaman hidup yang 
ditanam di kebun berjumlah 3.452 jenis (spesies) mewakili 1.267 marga (genus) atau 220 suku (famili). Koleksi anggrek yang diperlihara di ruang kaca sendiri tercatat berjumlah \pm 8000 spesimen terdiri dari 432 jenis dari 93 marga. Selain anggrek alam, koleksi lain yang cukup menarik, lengkap, dan menonjol adalah polong-polongan (Fabaceae), pinang-pinangan (Arecaceae), talas-talasan (Araceae), dan getahgetahan (Apocynaceae). Koleksi tanaman Kebun Raya Bogor terdiri dari 70\% berasal dari kepulauan Indonesia dan $30 \%$ berasal dari manca negara. Penambahan koleksi selain melalui eksplorasi ke hutanhutan yang ada di Indonesia juga hasil tukar-menukar biji tanaman dengan Kebun Raya lain di dunia (Ibrahim, 2006).

Salah satu koleksi yang terdapat di Kebun Raya Bogor adalah tanaman hias. Tanaman hias merupakan jenis tanaman yang bukan untuk dikonsumsi hasilnya melainkan untuk diambil keunikan dan keindahannya. Tanaman jenis ini bisa dijualbelikan maupun dinikmati sendiri keindahannya. Tanaman hias yang biasa dimanfaatkan untuk budidaya adalah tanaman yang memang sudah teruji dari segi keindahan, kecantikan, bentuk, dan manfaatnya. Tanaman hias memiliki fungsi utama untuk menambah nilai estetika pada suatu tanaman atau pada sebuah ruangan dan lahan taman.

Salah satu tanaman hias yang ditemukan di Kebun Raya Bogor adalah tanaman Hanjuang (Cordyline fruticosa). Tanaman ini merupakan tumbuhan monokotil yang sering dijumpai di taman sebagai tanaman hias.

Selain itu, tanaman Hanjuang sering dijumpai di taman dengan warna yang tampak berwarna ungu terang jika terkena sinar matahari langsung dan berwarna ungu jika tidak terkena matahari langsung. Namun demikian, sampai saat ini belum ada penelitian yang melakukan karakterisasi pada tanaman Hanjuang (Cordyline fruticosa), maka dari itu peneliti ingin melakukan karakterisasi tanaman hanjuang berdasarkan morfologi dan anatomi.

Penelitian ini memberikan informasi mengenai jaringan pengangkut, jaringan epidermis, stomata, zat ergastik, kandungan karotenoid dan antosianin, dan jaringan peyokong secara rinci dari tanaman Hanjuang (Cordyline fruticosa).

\section{METODE PENELITIAN}

\section{Waktu dan Tempat}

Penelitian ini dilakukan pada bulan Oktober 2018. Pengamatan dan pengambilan sampel dilakukan di Kebun Raya Bogor. Pemeriksaan sampel menggunakan mikroskop dilakukan di Laboratorium Struktur dan Perkembangan Tumbuhan Universitas Negeri Jakarta. Data yang didapat selanjutnya dijelaskan menggunakan metode deskriptif kualitatif dan mikroskopi.

Rancangan penelitian dirumuskan (Gambar 1).

\section{Rancangan Penelitian}

\begin{tabular}{|c|c|c|}
$\begin{array}{c}\text { Dibuat preparat dengan sayatan } \\
\text { longitudinal dan transversal }\end{array}$ & $\begin{array}{c}\text { Akar, batang, } \\
\text { dan daun }\end{array}$ & $\begin{array}{c}\text { xilem, floem, kolenkim, } \\
\text { epidermis, stomata, } \\
\text { kolenkim, karotenoid, zat } \\
\text { ergastik, dan antosianin }\end{array}$ \\
\end{tabular}

\section{Ditetesi larutan phloroglucinol dan air serta $\mathrm{HCl}$ dan $\mathrm{NaOH} 1 \mathrm{ml}$ untuk uji karotenoid dan antosianin \\ Diamati dengan miskroskop perbesaran 100- 400 kali dan diperoleh data gambar sampel}

Gambar 1. Bagan tahapan penelitian

\section{Populasi dan Sampel}

Populasi dalam penelitian ini adalah tanaman Hanjuang (Cordyline fruticosa) yang diperoleh dari Kebun Raya Bogor.Sampel dalam penelitian ini adalah akar, batang, dan daun dari tanaman Hanjuang (Cordyline fruticosa). Pada bagian akar diamati xilem, floem, dan kolenkim. Bagian batang diamati xilem, floem, kolenkim, dan epidermis. Bagian daun diamati stomata, kolenkim, karotenoid, zat ergastik,dan antosianin. 


\section{Teknik Pengumpulan data}

Sampel tanaman Hanjuang (Cordyline fruticosa) diperoleh dengan cara memotong bagian akar, batang, dan daun yang berada di Kebun Raya Bogor. Preparat dari jaringan tersebut disiapkan dengan cara menyayatnya secara longitudinal dan transversal. Preparat selanjutnya diamati di bawah mikroskop hingga diperoleh data berupa gambar sampel hasil pengamatan pada perbesaran 100-400 kali.

\section{Teknik Analisis Data}

Teknik analisis data yang dilakukan dalam penelitian ini adalah analisis deskriptif dan observasi. Penyajian analisis deskriptif dan observasi, yaitu berupa hasil uji sampel menggunakan metode tertentu pada bagian akar, batang, dan daun dari tanaman Hanjuang (Cordyline fruticosa). Analisis deskriptif yang dilakukan adalah:

1) Analisis xilem, floem, kolenkim pada bagian akar tanaman Hanjuang (Cordyline furticosa) di Kebun Raya Bogor.

2) Analisis stomata, kolenkim, karotenoid, zar ergastik dan antosianin pada bagian daun tanaman Hanjuang (Cordyline fruticosa) di Kebun Raya Bogor.

3) Analisis xilem, floem, kolenkim, dan epidermis pada bagian batang tanaman Hanjuang (Cordyline fruticosa) di Kebun Raya Bogor.

\section{HASIL DAN PEMBAHASAN}

Menurut Siti Sutarmi (2010) morfologi Tumbuhan adalah cabang ilmu Biologi yang mempelajari tentang bentuk dan susunan luar tubuh tumbuhan beserta fungsinya dalam kehidupan tumbuhan. Karakter morfologi merupakan ciri yang umum digunakan untuk mengklasifikasikan tumbuhan. Morfologi tumbuhan berdasarkan kesamaan ciri dapat dikelompokkan dalam kelompok taksa tertentu (Gembong dikutip oleh Sa'adah, 2015).

Menurut Sri Mulyani (2006) anatomi tumbuhan adalah salah satu cabang ilmu Biologi yang mempelajari tentang struktur dalam tumbuhan beserta fungsinya. Karakter anatomi digunakan sebagai dasar taksonomi untuk menempatkan suatu tumbuhan pada tingkat takson tertentu.

Tumbuhan memiliki berbagai macam jaringan yang membentuk organ tumbuhan. Jaringan tumbuhan dibedakan berdasarkan tempat dalam tumbuhan,tipe sel, fungsi, asal-usul, dan tahap perkembangannya. Berdasarkan jumlah tipe sel penyusunnya, jaringan dibedakan menjadi dua, yaitu jaringan sederhana dan jaringan rumit. Parenkim, kolenkim, dan sklerenkim adalah jaringan sederhana, sedangkan xilem, floem, dan epidermis adalah jaringan rumit.

\section{Morfologi tanaman Hanjuang (Cordyline fruticosa)}

Pengamatan tanaman Hanjuang (Cordyline fruticosa) secara morfologi memberikan informasi bahwa daun berbentuk bangun lanset, ujungnya runcing, pangkalnya runcing, tepinya berombak, susunan tulangnya menyirip, dagingnya seperti kertas, dan warnanya ungu. Batang arah pertumbuhannya secara monopodial. Akar berbentuk serabut. 


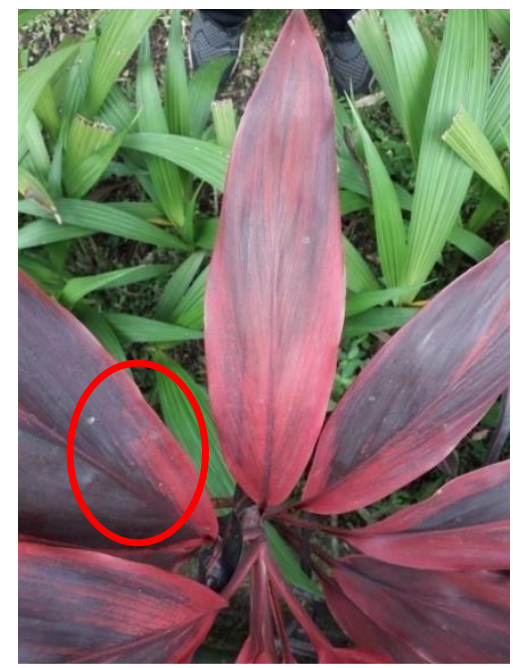

Gambar 2. Daun tanaman Hanjuang (Cordyline fruticosa) saat tidak terkena cahaya matahari

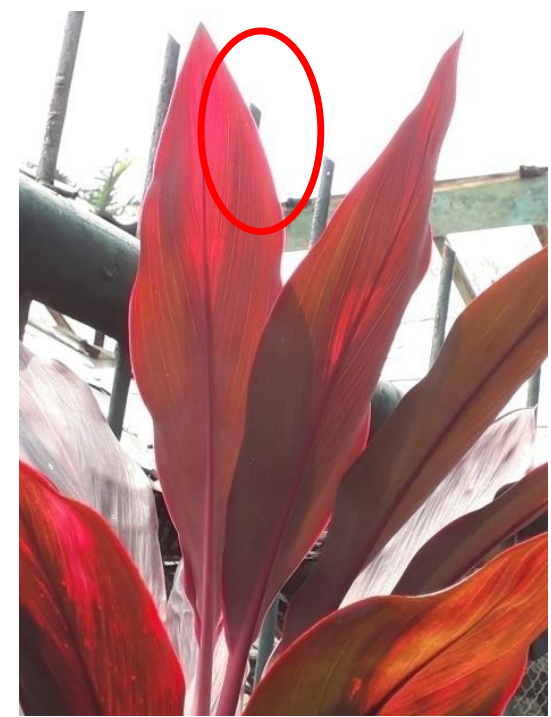

Gambar 3. Daun tanaman Hanjuang (Cordyline fruticosa) saat terkena cahaya matahari

Tanaman Hanjuang (Cordyline fruticosa) memiliki daun dengan susunan tulang menyirip karena menyesuaikan dengan habitat tanaman Hanjuang (Cordyline fruticosa) tumbuh. Susunan daun tanaman Hanjuang (Cordyline fruticosa) yang menyirip menyerupai seperti susunan tulang ikan. Susunan tulang daun yang menyerupai susunan tulang ikan berimplikasi dengan komponen daun lainnya. Implikasi yang memungkinkan adalah ujung dan pangkal daun berbentuk runcing. Hal tersebut bertujuan untuk proses metabolisme dari tanaman Hanjuang (Cordyline fruticosa) (Gambar 2).

Tepi tanaman Hanjuang (Cordyline fruticosa) yang berombak mirip seperti tepi daun tanaman Lidah Mertua (Sansevieria spp.). Daging daun tanaman Hanjuang (Cordyline fruticosa) seperti kertas yang mirip dengan tanaman Pisang (Musa spp.). Bangun daun pada tanaman Hanjuang (Cordyline fruticosa) berbentuk lanset yang mirip seperti tanaman Lidah Mertua (Sansevieria spp.). Permukaan daun tanaman Hanjuang (Cordyline fruticosa) halus seperti daun bunga Kembang Sepatu (Hibiscus rosa-sinensis).

Warna daun tanaman Hanjuang (Cordyline fruticosa) menunjukkan warna ungu karena warna yang diserap dari cahaya matahari untuk fotosintesis, yaitu warna merah dan biru atau ungu. Hal ini karena warna lain dari cahaya matahari di refleksikan atau diserap lalu direfleksikan. Warna ungu dapat diserap oleh tanaman karena nilai intensitasnya lebih rendah dari warna lainnya, yaitu $10^{-14}$. Warna biru yang memiliki nilai intensitas $10^{-12}$ akan menginduksi pertumbuhan daun dan warna merah yang 
memiliki nilai intensitas $10^{4}$ dikombinasikan dengan warna biru akan merangsang perbungaan. Hal ini disebabkan tanaman Hanjuang (Cordyline fruticosa) hanya memiliki daun dan tidak memiliki bunga maka warna biru akan lebih mudah diserap oleh tanaman Hanjuang (Cordyline fruticosa) dan warna merah akan direfleksikan (Gambar 2 dan 3).

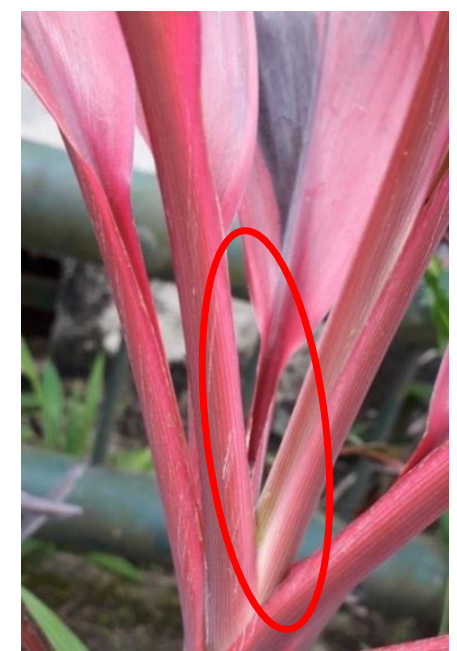

Gambar 4. Batang tanaman Hanjuang (Cordyline fruticosa)

Arah pertumbuhan batang tanaman Hanjuang (Cordyline fruticosa) secara monopodial. Tanaman yang tumbuh secara monopodial bagian kuncup apikalnya akan terus tumbuh. Kuncup yang terus tumbuh dapat menyebabkan bagian kuncup lateral mengalami dormansi. Bila kuncup apikal di potong maka kuncup lateral akan hilang masa dormansinya dan mengakibatkan arah perumbuhannya menjadi simpodial (Gambar 4).

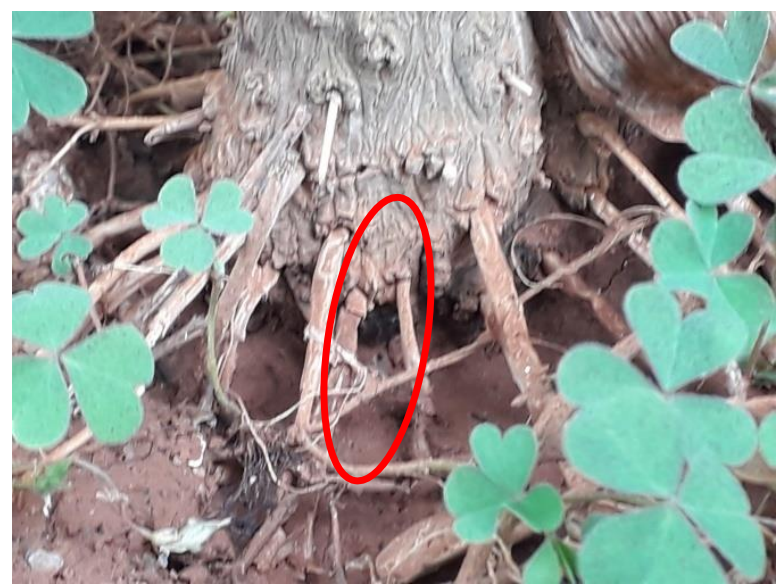

Gambar 5. Akar tanaman Hanjuang (Cordyline fruticosa)

Akar tanaman Hanjuang (Cordyline fruticosa) berbentuk serabut karena akar sekundernya lebih banyak bercabang.Hal ini disebabkan akar primernya telah hilang dan digantikan dengan akar sekunder (Gambar 5).

\section{Anatomi tanaman Hanjuang (Cordyline fruticosa)}

Pengamatan tanaman Hanjuang (Cordyline fruticosa) secara anatomi memberikan informasi bahwa daun pada sayatan longitudinal memiliki jaringan penyokong berupa kolenkim, stomata berbentuk aktinositik, zat ergastik berupa kristal jarum, mengandung antosianin dan tidak mengandung karotenoid.

Batang pada sayatan transversal memiliki jaringan pengangkut berupa xilem yang lebih besar daripada floem, terdapat jaringan epidermis yang sangat dekat dengan jaringan pengangkut, dan 
memiliki jaringan penyokong berupa kolenkim. Akar pada sayatan transversal berbentuk radial pada jaringan pengakut dan jaringan penyokong berupa kolenkim.

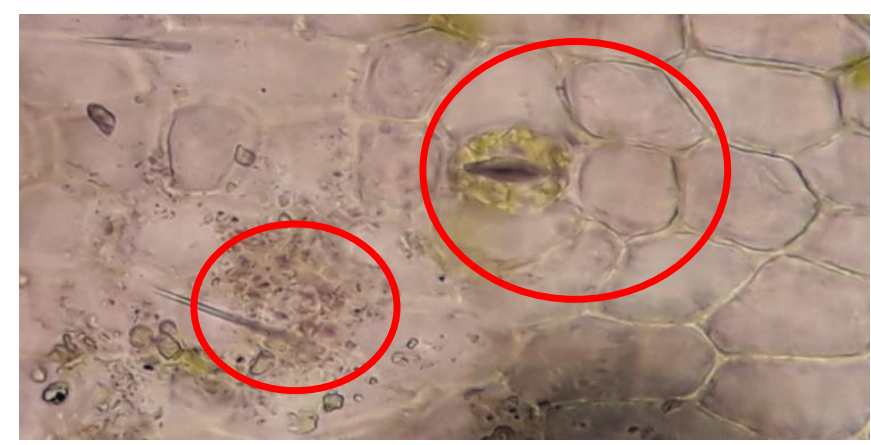

Gambar 6. Stomata aktinositik dan kristal jarum perbesaran 100 kali

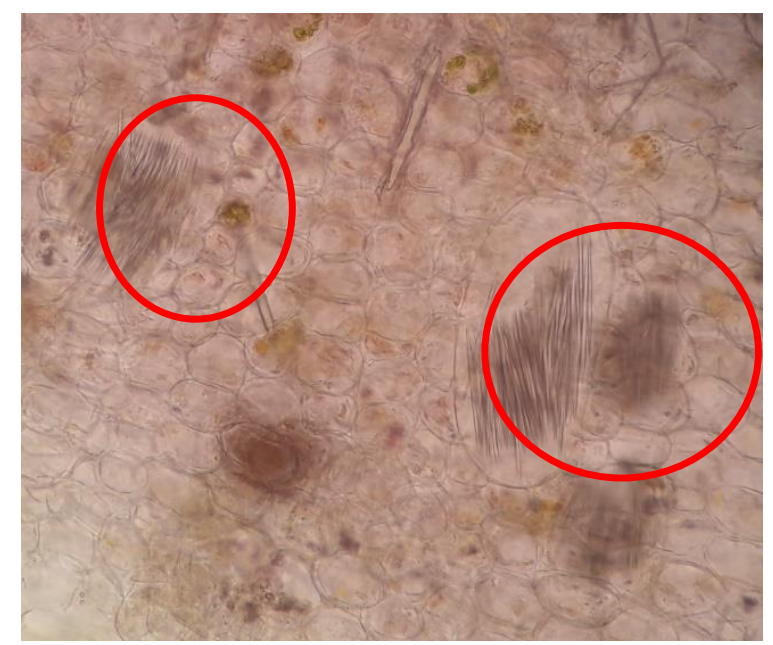

Gambar 7. Kristal jarum perbesaran 100 kali

Tanaman Hanjuang (Cordyline fruticosa) yang memiliki sayatan longitudinal pada daun terdapat stomata berbentuk aktinositik (Gambar 6). Stomata hanya terdapat pada permukaan daun yang berfungsi sebagai tempat pertukaran gas dan bentuk aktinositik merupakan stomata dengan sel-sel tetangga yang pipih dan mengelilingi stomata dalam susunan berbentuk lingkaran. Zat ergastik yang berupa kristal jarum merupakan komponen non-protoplasma karena zat ergastik merupakan hasil metabolisme yang berfungsi untuk pertahanan, pemeliharaan struktur sel, dan penyimpanan cadangan makanan (Gambar 7). Zat ergastik terdiri dari dua komponen, yaitu padat dan cair. Zat ergastik yang bersifat padat terdiri atas pati dan kristal sedangkan zat ergastik yang bersifat cair terdiri atas asam organik, karbohidrat, protein, lemak, tannin, antosianin, alkaloid, dan minyak eteris. Bentuk kristal jarum merupakan zat ergastik yang hanya terdapat di permukaan dan dalam daun. Hal ini mirip dengan anatomi daun tanaman Pisang (Musa spp.) berdasarkan zat ergastik. 


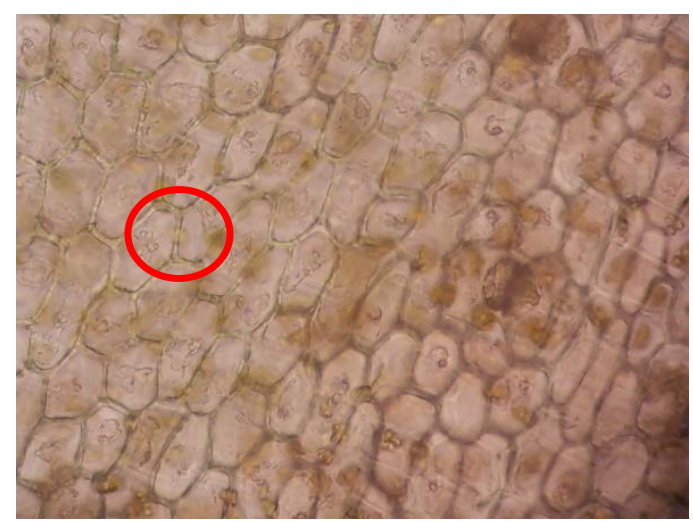

Gambar 8. Kolenkim pada daun 100 kali

Jaringan penyokong berupa kolenkim yang memiliki fungsi untuk menyokong organ-organ tanaman yang sedang mengalami masa pertumbuhan. Kolenkim banyak ditemukan pada tanaman herba (herbaceus) dan kolenkim yang memiliki kloroplas akan berfungsi sebagai fotosintesis. Kolenkim yang berada di daun berfungsi untuk menguatkan organ daun yang sedang mengalami pertumbuhan (Gambar 8).

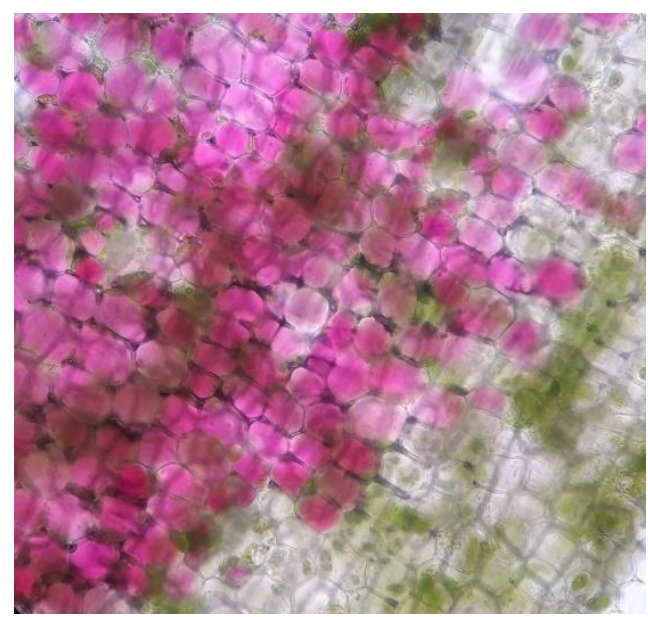

Gambar 9. Daun Hanjuang berwarna ungu saat diberikan air

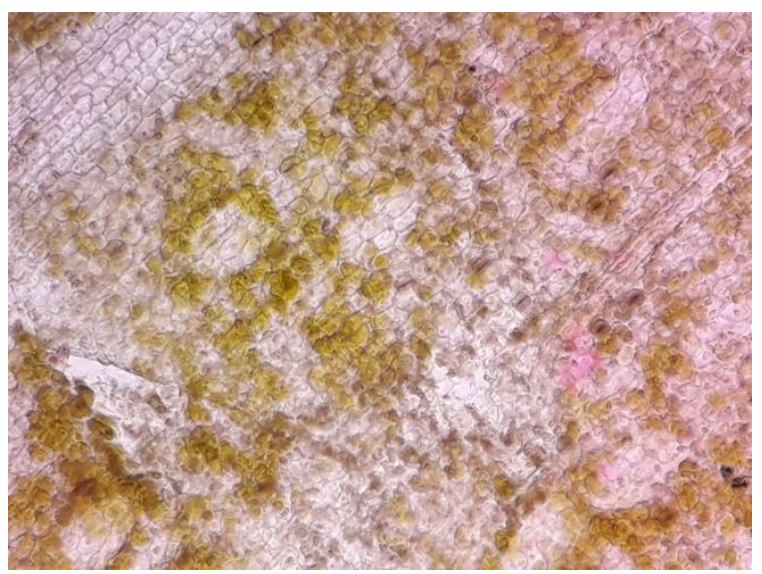

Gambar 10. Daun Hanjuang berwarrna kuning saat diberikan larutan $\mathrm{HCl}$ 


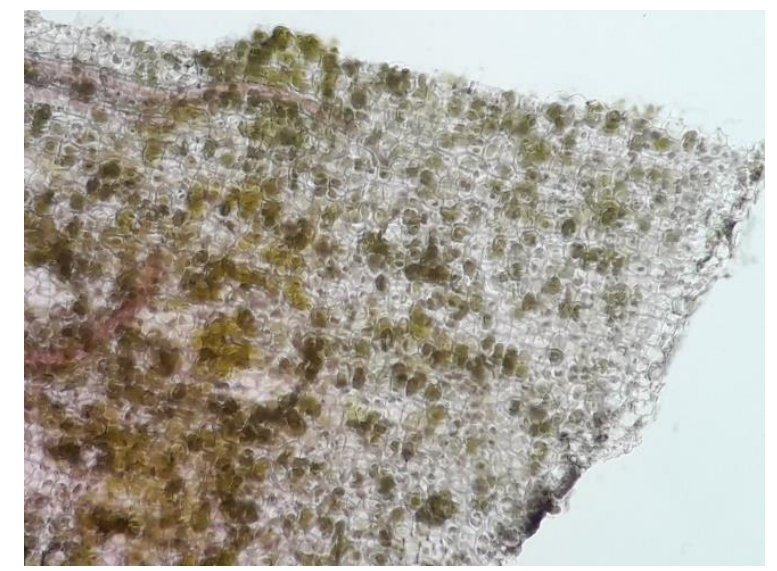

Gambar 11. Daun Hanjuang berwarna hijau saat diberikan larutan $\mathrm{NaOH}$

Antosianin merupakan zat warna alami golongan flavonoid yang memberikan warna ungu (Gambar 9) dan karotenoid merupakan pigmen organik yang ditemukan dalam kloroplas dan kromoplas. Antosianin mengalami perubahan wana menjadi warna kuning saat diberikan larutan asam $(\mathrm{HCl})$ dan warna hijau saat diberikan larutan basa berupa $\mathrm{NaOH}$ (Gambar 10 dan 11). Hal ini disebabkan struktur antosianin yang dipengaruhi oleh $\mathrm{pH}$. Akan tetapi, tanaman hanjuang tidak memiliki kandungan karotenoid karena saat diberikan larutan $\mathrm{HCl}$ dan $\mathrm{NaOH}$ mengalami perubahan warna.

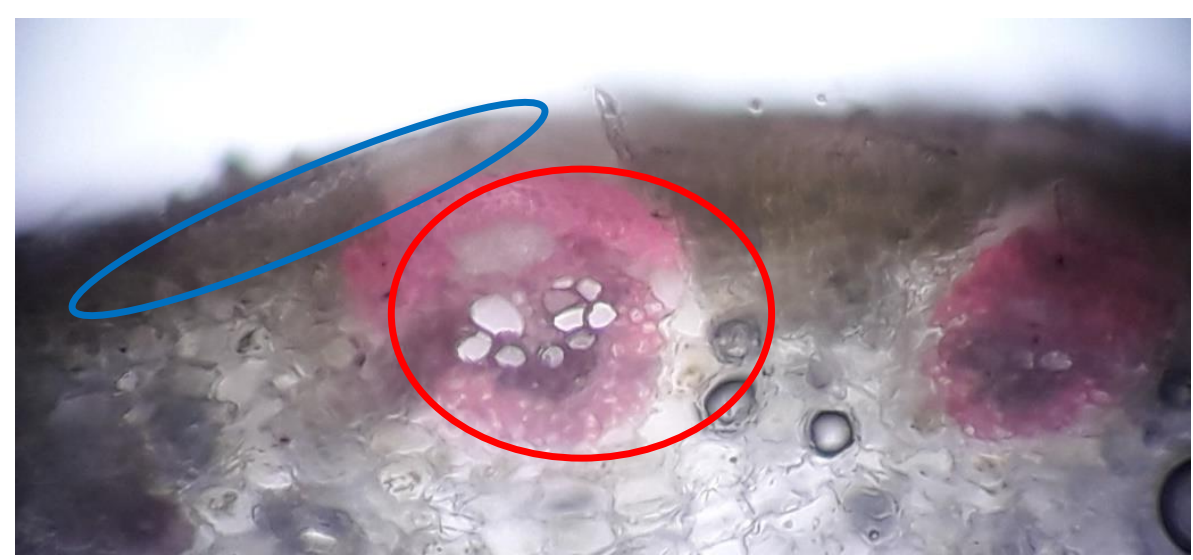

Gambar 12. Jaringan pengangkut (bulat merah) dan jaringan epidermis (bulat biru) perbesaran 400 kali

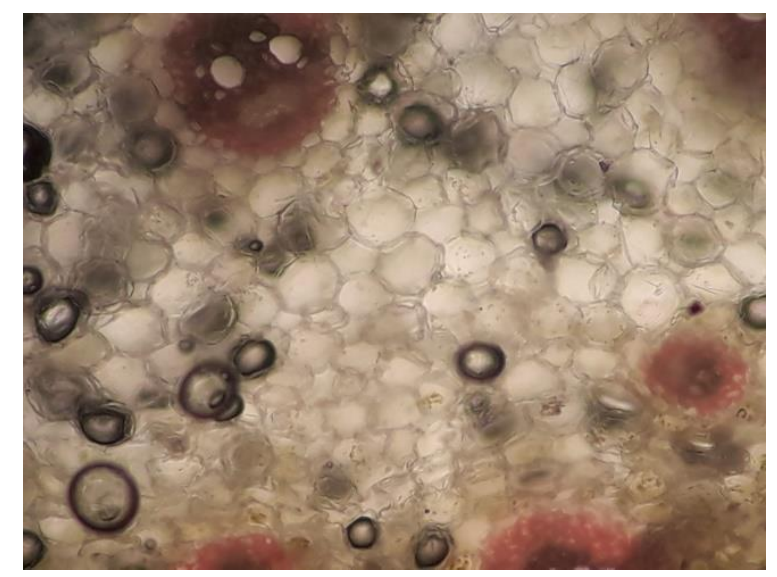

Gambar 13. Jaringan pengangkut dan kolenkim batang perbesaran 100 kali

Sayatan trasnversal pada batang memiliki jaringan pengangkut berupa xilem dan floem.Xilem merupakan jaringan vaskular yang mengangkut air dan mineral dari akar ke seluruh tanaman dan floem 
merupakan jaringan vaskular yang mengangkut hasil fotosintesis dari daun ke seluruh tanaman (Gambar 12). Dalam jaringan pengangkut tanaman Hanjuang (Cordyline fruticosa) mirip dengan tanaman jenis Pakis Haji (Cycas rumphii), yaitu xilem yang lebih besar daripada floem dan memiliki tipe kolateral tertutup berdasarkan letak xilem dan floem. Tipe kolateral tertutup merupakan xilem dan floem yang diantaranya tidak terdapat kambium.Xilem lebih besar daripada floem karena xilem mengangkut air dan mineral yang merupakan media untuk fotosintesis dan reaksi kimia lainnya pada tanaman. Jika xilem berukuran kecil maka kinerjanya tidak akan baik.

Jaringan epidermis merupakan jaringan lapisan yang tebal selapis dan menutupi permukaan organ serta tidak memiliki kloroplas. Jaringan epidermis dekat dengan jaringan pengangkut karena memiliki fungsi untuk melindungi organ dalam tanaman. Jika jaringan epidermis mengalami kerusakan maka agen penginfeksi akan mudah masuk dan menginfeksi seluruh jaringan tanaman. Jaringan penyokong berupa kolenkim sama dengan kolenkim yang terdapat di daun tetapi kolenkim yang di batang berfungsi untuk menguatkan organ batang yang sedang mengalami masa pertumbuhan (Gambar 13).

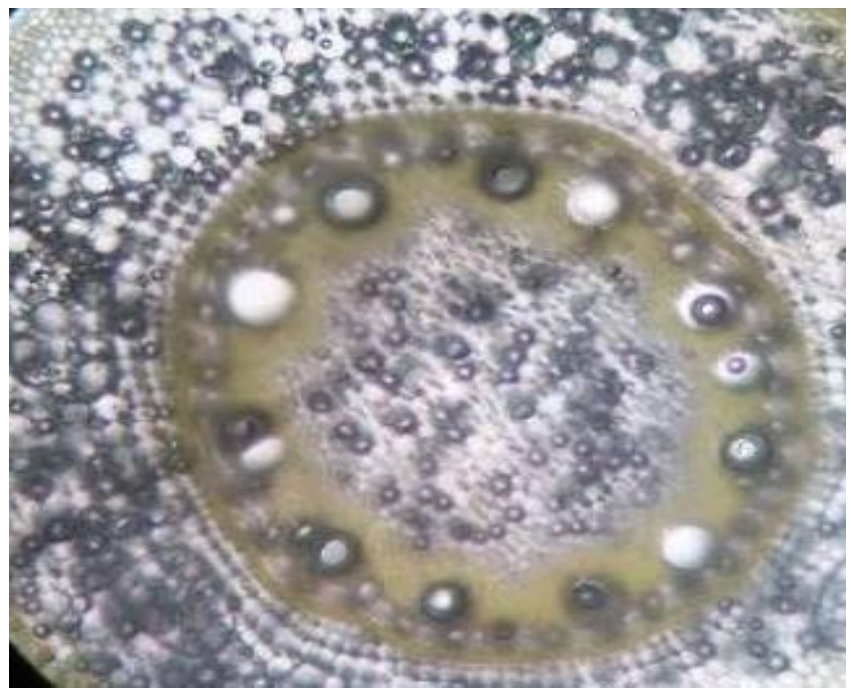

Gambar 14. Jaringan pengangkut dan kolenkim pada akar perbesaran100 kali

Sayatan transversal pada akar dengan jaringan pengangkut berbentuk radial karena posisi xilem dan floem tersusun berselang-seling. Jaringan penyokong berupa kolenkim yang sama dengan kolenkim yang terdapat di daun dan batang tetapi kolenkim yang di akar memiliki fungsi untuk menyokong dan menguatkan organ akar agar tanaman tetap berdiri tegak (Gambar 14).

\section{KESIMPULAN}

Secara morfologi daun hanjuang memiliki ujung dan pangkal yang runcing, susunan tulang menyirip, daging seperti kertas, bangun berbentuk lanset, permukaan halus, tepi berombak, berwarna ungu terang saat terkena cahaya matahari dan warna ungu gelap saat tidak terkena cahaya matahari, serta memiliki jenis daun berpelepah. Batang hanjuang memiliki arah pertumbuhan secara monopodial sedangkan akarnya merupakan serabut. Secara anatomi bagian daun, batang, dan akar hanjuang memiliki jaringan penyokong berupa kolenkim. Batang dan akar memiliki jaringan pengangkut tetapi jaringan pengangkut pada batang berupa xilem yang lebih besar daripada floem dan pada akar berbentuk radial. Daun memiliki stomata berbentuk aktinositik dan zat ergastik berupa kristal jarum. Stomata dan zat ergastik hanya terdapat pada bagian daun dan pada bagian batang terdapat jaringan epidermis yang berdekatan dengan jaringan pengangkut. Pada bagian daun saat diberikan air, warna daun menjadi warna ungu. Warna daun mengalami perubahan saat diberikan larutan asam berupa $\mathrm{HCl}$ menjadi warna kuning dan saat diberikan larutan basa berupa $\mathrm{NaOH}$ menjadi warna hijau. Hal ini menunjukkan bahwa tanaman Hanjuang (Cordyline fruticosa) memiliki kandungan antosianin dan tidak memiliki kandungan karotenoid. 


\section{UCAPAN TERIMA KASIH}

Terima kasih kepada Kebun Raya Bogor yang telah memberikan kesempatan mengambil sampel dalam penelitian dan Laboratorium Struktur dan Perkembangan Tumbuhan Universitas Negeri Jakarta yang telah memberikan bantuan berupa alat penunjang dalam penelitian ini.

\section{REFERENSI}

Ibrahim, Yusuf. (2006). Studi Permintaan Manfaat Rekreasi di Pusat Konservasi Tumbuhan Kebun Raya Bogor/LIPI. Skripsi: Institut Pertanian Bogor.

Mulyani E.S, Sri. (2006). AnatomiTumbuhan. Yogyakarta: Kanisius.

Sa'adah, Lilis. (2015). Karakterisasi Morfologi dan Anatomi Selada Air (Nasturtium spp.) di Kabupaten Batang dan Semarang Sebagai Sumber Belajar Dalam Mata Kuliah Morfologi dan Anatomi Tumbuhan. Skripsi. Universitas Negeri Islam Walisongo.

Subarna, A. (2003). Kebun Raya Bogor. Bogor.

Tjitrosomo, Siti Sutarmi, dkk. (2010). Botani Umum 1. Bandung: Angkasa.

Tjitrosoepomo, Gembong. (2007). Morfologi Tumbuhan. Yogyakarta: Gadjah Mada University Press. 